○細井裕司，今泉“敏，村田清高，小池靖夫，太田文彦 （近畿大学 医学部 耳鼻咽喉科学教室）

1. はじめに

語音聴力検查は, 聴力の程度を知るためと聴覚障害の部位診断を行なうととを目的として行な われる。しかし，語音弁別能力は，聴力型など他の要因の影響をうけるために障害部位との関係 が明確でなく，後者の目的は充分に達せられてはいない。そてで我々は，語音弁別能力から聴力 型の影響を除去する方法を提案し1)，聴覚障害の部位診断における語音聴力検査の意義を検討し た。

\title{
2. 実験方法および結果
}

実験 1：実験対象は伝音性難聴 5 例, 感音性難聴 20 例（55内耳性難聴 10 例, 後迷路性難聴 10 例 )である。症例 $\mathrm{k}(\mathrm{k}=1 \sim 25)$ のオージオグラムをウィンドウ法2)で作成した線形位相の FIRディジタルフィルタで近似した。次に, 日本オージオロジー学会の 57 式語表の中から最も 雑音が少なく明瞭度の高い発声を選んで $20 \mathrm{KHz}, 12 \mathrm{bits}$ で量子化した。との語音を上記のフィ ルタに通し，10名の聴力正常者にヘッドホンを用いて右耳から提示し，50 単音節に対する正答 率をもって語音弁別能力を測定した。難聴者 $\mathrm{k} に$ 対応する聴力正常者の語音弁別能力の平均值 $\mu \mathrm{k}$ （\%）と標準偏差の $\sigma \mathrm{k}(\%)$ を求めた。さらに, 難㯖者 $\mathrm{k}$ の語音弁別能力 $\overline{\mathrm{d}} \mathrm{k}$ と前述の $\mu \mathrm{k}$ との距離を $\sigma \mathrm{k}$ で正規化して正規化距離 $\overline{\mathrm{d}} \mathrm{k}\left(\overline{\mathrm{d}} \mathrm{k}=\frac{\mathrm{dk}-\mu \mathrm{k}}{\sigma \mathrm{k}}\right)$ を求めだ。 $\overline{\mathrm{d}} \mathrm{k}$ の累積度数 (\%) 難聴の種類別に Fig. 1(a)に示した。その結果,层音性わよび内耳性難聴例の正規化距離は土2の範囲にそれぞれの 100 $\% ， 60 \%$ が分布するのに対し，後迷路性難聴例の $60 \%$ がー2 未满の值をもつととが示された。

実験 2 : 次に実験 1 の結果を, 臨床的に有用な検査として応用し得るかどうかを調べた。その ために実験 1 で用いたのとは別の 66 症例 100 耳に対して実験 1 のデータから正規化距離を推定 した。まず，推定精度を上げるために人工的に作成した聴力型 $\mathrm{k}(\mathrm{k}=26 \sim 35)$ を追加し，それ に対する $\mu_{\mathrm{k}}, \sigma \mathrm{k}$ を実験 1 と同様の手順で求めた。推定のために山型, 高調音急壁型などの聴力 型の類似性と語音弁別に特に重要な $500 \mathrm{~Hz} \sim 2 \mathrm{KHz}$ 付近の傾斜の類似度, 著明に特性が変化す る周波数の一致などの評価基準を用いて語音弁別能力の推定範井(下限と上限，またはどれかひ

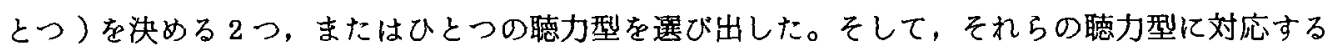

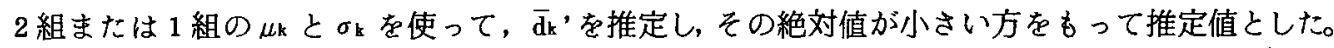
調べた 100 耳のうち今回実験した 35 種の聴力型から語音弁別能力が推定できたのは，54耳であ った。その他は類似の聴力型の選択が困難であった。推定できたものの内訳は, 层音性難聴例 5 耳, 内耳性難聴例 31 耳, 後迷路性難㯖例 18 耳である。難聴者 $\left(\mathrm{k}^{\prime}=1 \sim 54\right)$ 亿つて実験 1 と同

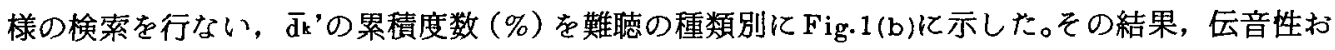

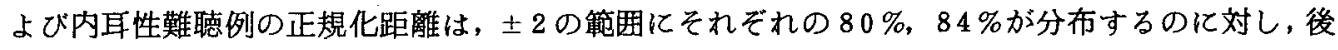
迷路性難聴例の $56 \%$ が-2 未満の值をとった。てれは, 実験 1 で用いた以外の症例に対する正規 化距離の推定值が実験 1 の結果と類似の傾向をもつてとを示している。

3. 結論および考察

実験 1 の結果加ら。

（1)卮音性およひ肉耳性難聴例の語音弁別能力は, 聴覚系の周波数特性（本実験では聴力型）から 
ある程度推定し得る可能性がある。

(2)しかし, 後迷路性難聴例では, 聴覚系の周波数特性による語音弁別能力の制限に加えて,さ らに特殊な現象が存在する可能性がある。

また実験 2 の結果から、

(3)あらかじめ用意されたモデルの聴力型とそれに対応する語音弁別能力の平均值と標準偏差が 与えられていれば, 種々の聴力型に対応する正規化距離を推定するてとができ, その症例の語音 弁別能力の高低を判定し, 後迷路性難聴の検出をするととがある程度可能である。

現時点では，すべての症例に対しては，語音弁別能力の正規化距離の推定值を算出するととは 困難であった。との問題は, 聴力型のモデルの数を増すととによって解決するととが可能と思わ れる。また各種難聴者で聴力型から考えられる異聴とどのように異なった異聴傾向があるかを調 べるととは，聴覚系の言語音に対する働きを考える上で有用と思われる。

Fig. 1. (a)

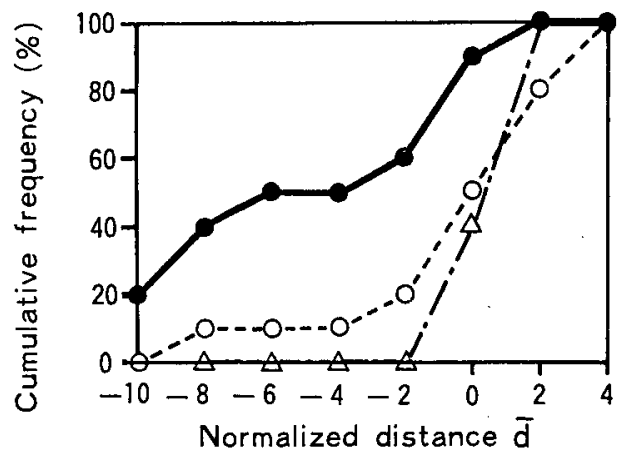

Fig. 1. (b)

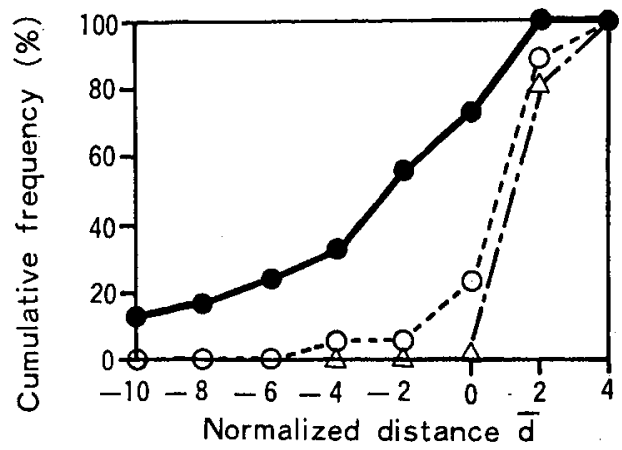

- Retrocochlear hearing loss

O Inner ear hearing loss

$\Delta$ Conductive hearing loss

Fig. 1 .

Cumulative frequency of the normalized distance in percent.

(a) Normalized distance between the discrimination score of a patient's ear and the average discrimination score of normal subjects for filtered monosyllables.

(b) Normalized distance between the discrimination score of a patient's ear and the estimated discrimination score as mentioned in the text.

参考文献

1）細井裕司 他：“聴力型と語音聴取能”, Audiology Japan, 2 3, 5, pp. 525-526(1980),

2) L. Rabiner:" Theory and Application of Digital Signal Processing ", Prentice Holl Int., London ( 1975 ). 